\title{
Technological Advocacy of Migrant Workers in The Pre Placement Based on Personal Legal Assistance
}

\author{
Asri Wijayanti, Bambang Sugeng Ariadi Subagyono, Agus Yudha Hernoko, Zahri Vandawati \\ Chumaida, Yayuk Sugiarti
}

\begin{abstract}
Equal rights and opportunities without discrimination to obtain decent jobs and livelihoods are often underestimated by some countries. The placement of Indonesian migrant workers abroad must receive serious attention. The impact can result in the loss of property to private migrant workers and their families until the loss of life. Legal safeguards are needed in the form of prevention of legal violations through advocacy for assisting Indonesian migrant workers during pre placement on the personal legal based. Due to this fact, our research focuses on how the design of personal legal advocacy can fulfill the right to work and livelihoods that are appropriate for humanity for Indonesian migrant workers. This research used normative juridical with a socio-legal approach in Indonesia. The findings showed that advocacy based on personal legal assistance can be a positive element so that the right to work and a decent living for humanity for Indonesian migrant workers can be fulfilled
\end{abstract}

Index Terms - Indonesian migrant workers, the right to work, personal legal assistance.

\section{INTRODUCTION}

Equal rights and opportunities without any discrimination to get jobs and decent livelihoods must become serious attention from all countries. Working abroad is indeed relatively for earning higher wages compares to working in the home country.

The protection of migrant workers and their families is in fact not maximized in Indonesia, China [1] and Canada [2] [3]. There are positive and negative impacts on the existence of migrant workers for Indonesia [4] The positive impact is the increasing of state foreign exchange [4] and work experience. [5] The negative impact on the placement of migrant workers is the loss of property to private migrant workers and their families until the loss of life. [6].

The number of migrant workers who are working abroad has not ascertained yet, depending on the source. [7] There are 283,640 people of migrant workers in 2018 registered by the National Agency for the Placement and Protection of

Indonesian Workers $(=\mathrm{BNP} 2 \mathrm{TKI})$. Documented migrant

Revised Version Manuscript Received on 10 September, 2019.

Asri Wijayanti, University Muhammadiyah of Surabaya, Jawa Timur, Indonesia. (Email: asri.wijayanti@fh.um-surabaya.ac.id)

Bambang Sugeng Ariadi Subagyono, Airlangga University, Jawa Timur, Indonesia. (Email: bambang.sas@ fh.unair.ac.id)

Agus Yudha Hernoko, Airlangga University, Jawa Timur, Indonesia.

Zahri Vandawati Chumaida, Airlangga University, Jawa Timur, Indonesia.

Yayuk Sugiarti, University Wiraraja, Jawa Timur, Indonesia. (Email: yayuksugiarti@wiraraja.ac.id). workers $2,862,495$ while $1,870,060$ are not documented as recorded in the Ministry of Foreign Affairs in 2017. The people case was collected by Crisis Center of BNP2TKI PUSLITFO totaling 4,894 in 2015. [8]

The protection of migrant workers has been regulated in Law 18 of 2017 concerning the Protection of Indonesian Migrant Workers jo. Law 13 of 2003 concerning Employment jo. Law No. 6 of 2012 concerning Ratification of the International Convention on the Protection of the Rights of All Migrant Workers and Members of Their Families and Members of Their Families) and Law No. 7 of 1984 concerning Ratification of the Convention concerning the Elimination of

All Forms of Discrimination Against Women (Convention on the Elimination of All Forms of Discrimination Against Women). Migrant workers for Indonesia protection is divided into three periods, namely before working, at working and after working. PMI protection is expected to be better if there are protections before the existence of migrant workers abroad. Legal protections are needed in the form of prevention of legal violations through migrant workers assistance advocacy during pre-legal based personal placements. From the description above, the problem arises, how can formal legal-based advocacy technology provide legal protection for migrant workers during the pre-placement period?

\section{RESEARCH METHOD}

The method of collecting data used a library research. References are taken from articles about migrant workers. Data analysis used deduction with comparison methods between one to another and then drew conclusion to strengthen one of them.

\section{LITERATURE REVIEW}

A.Equal rights and opportunities without any discrimination to obtain decent work and livelihood

Equal rights and opportunities without discrimination to get jobs and decent livelihoods are part of human rights. Based on Article 6 paragraph (1) of Law 18/2017, migrant worker's rights consist of choosing work in accordance with their competencies; obtaining access to education and 


\section{TECHNOLOGICAL ADVOCACY OF MIGRANT WORKERS IN THE PRE PLACEMENT BASED ON PERSONAL LEGAL ASSISTANCE}

training; getting an access to correct workplace information; obtaining humane services at work before work, during work and after work; worship; getting a decent wage; legal protection and assistance; communication access; the right of association and assembly; guarantee of work safety and security.

Require the State to intervene in regulating the freedom to choose a place to work. The right to choose a workplace according to competence is the subjective right of every human being and it must be maintained to be protected from interference from outside. Must obtain substantial and procedural protection through regulatory instruments, policies and court decisions..

There are social and individual demands that must be deciphered by the Government in taking actions that encourage the increase of migrant worker protection. Democratic governance can improve the quality of migrant workers for the welfare of workers and their families. The government is also demanded to be able to facilitate the empowerment of migrant workers for Indonesia to be able to realize for their home region, as stated by According to Ryaas Rasyid, "the implementation of regional autonomy is to develop democratic life, encourage efforts to empower communities in development, strengthen the ability and position of local government, improve public services and welfare communities through regional development According to Ryaas Rasyid, "the implementation of regional autonomy is expected to provide great benefits in the life of society, nation and state, especially to develop democratic life, encourage efforts to empower communities in development, strengthen the ability and position of local government, improve public services and welfare community through regional development. [9]

\section{B. Formal legal based assistance technology}

Formal legal-based assistance technology is a scientific method carried out by vocal points (assistants) to achieve practical goals [10] in assisting migrant workers for Indonesia when facing legal problems during pre-placement based on personal / fair legal legal (formal) mapping. [11]

The root of the problem facing legal problems during pre-placement can occur in the area of origin until migrant workers is on the border of Indonesia. With formal legal assistance, it can be realized that early prevention of migrant workers placement is predicted to cause problems in the workplace.

Formal legal-based assistance would be carried out optimally by involving socio-economic potential, community potential through empowering community forums facilitated by related sectors and synchronized with original regional planning and supported and carried out thoroughly by all relevant community members.

The legal personal assistance model consists of 4 elements, namely: Assistance in the substance of the related subject matter; assistance in the substance of the related problem; assistance of formal procedures related problems; assistance of related personal procedures

B1. Assistance in the substance of the related subject matter.

Assistance in the substance of related subject matter is a scientific method carried out by the vocal point (assistant) to assist and help migrant workers in facing legal problems during pre-placement based on appropriate legal mapping in the analysis of related legal subjects (actors). Actors related to the placement of migrant workers during pre-placement are prospective migrant workers, families of migrant workers, companies placed by migrant workers, business partners, employers, social security administrators, the central, local, to village governments. These actors are essentially legal aid providers, legal aid recipients and legal aid providers.. A practical guide / module is needed for legal aid providers who will provide advocacy to migrant workers

\section{B2. Assistance in the substance of the related problem}

Assistance in the substance of the related problem is a scientific method carried out by the vocal point (assistant) to assist and help migrant workers for Indonesia when facing legal problems during pre-placement based on proper legal mapping on the analysis of related legal objects. Assistance that is based on formal objects includes administrative protection (completeness and validity of the placement documents and determination of conditions and conditions of work) and technical protection (access to information, quality improvement, social security, facilitation of prospective migrant workers for Indonesia rights collection, strengthening the role of relevant officials, integrated services, coaching and supervision)

\section{B3. Assistance of formal procedures related problems}

Formal procedure related assistance is a scientific method carried out by vocal points (assistants) to assist and help migrant workers when facing legal problems during pre-placement based on appropriate legal mapping in the analysis of related legal substances. Proper mapping can be done through the stages of gathering facts, to look for initial truths; classify the nature of legal issues; identify and select relevant legal issues; making legal discoveries relating to legal issues and implementing the law

\section{B4. Assistance of related personal procedures \& Results}

Assistance of related personal procedures is a scientific method carried out by vocal points (assistants) to assist and help migrant workers for Indonesia when facing legal problems during pre-placement based on the psychological conditions of migrant workers for Indonesia and their families. Assistance to personal procedures can be done by applying the principles of local wisdom related to the dispute resolution efforts.

\section{ANALYSIS}

Equal rights and opportunities without discrimination to obtain jobs and livelihoods that are suitable for migrants are a very important thing to get legal protection. Migrant workers protection is regulated in the rules of national law and international law. Migrant workers 's protection before work must be a serious concern from the Indonesian government. The existing rules must be implemented through a structured step involving all elements of society.

Published By:
Blue Eyes Intelligence Engineering
\& Sciences Publication




\section{Legal Basis}

Migrant workers for Indonesia protection is constitutionally regulated in:

- Article 27 paragraph (2): "Every citizen has the right to work and livelihood that is appropriate for humanity";

- Article 28 D paragraph (1): "Every person has the right to recognition, guarantee, protection and fair legal certainty and equal treatment before the law"; Article 28D Paragraph (2): "Every person has the right to work and receive compensation and fair and proper treatment in work relations.

This provision is further elaborated in several laws and regulations, namely:

- Law No. 39 of 19999 concerning Human Rights jo.

- Law No. 21 of 2000 concerning Labor Unions, jo.

- Law No. 13 of 2003 concerning Employment jo

- Law No. 2 of 2004 concerning the settlement of Industrial Relations Disputes jo.

- Law No. 40 of 2004 concerning the SJSN

- Law No. 40 of 2007 concerning Limited Liability Companies, jo.

- Law No. 25 of 2009 concerning Public Services, jo.

- Law No. 16 of 2011 concerning Legal Aid jo.

- Law Number 18 Year 2017 concerning Protection of Indonesian Migrant Workers,

\section{World Convention}

Universal protection of migrant workers is initially contained in the Universal Declaration of Human Rights. It is further elaborated in The International Covenant on Civil and Political Rights (ICCPR) and the International Covenant on Economic, Social and Cultural Rights (ICESCR).

In particular, there are three conventions governing migrant workers, namely the Convention on the Rights of All Migrant Workers and Members of Their Families. Migration for employment (Convention 97 in 1949) and Migrant Workers (Convention 143 of 1975).

\section{E.Discussion}

This research has been carried out based on the assistance activities that have been carried out by the Migrant Workers NGO. The assistance process was carried out in an effort to help recover collateral for obtaining decent work and livelihoods. Working is someone's right. A person has the right to be able to work anywhere in accordance with the competencies he has. Protection of migrant workers requires an integrated system, involving the central and regional government and society.

It took the role of the Regional Government to provide integrated one-stop services and facilitate the departure and return of migrant workers that can be implemented through a public service mechanism. Before a migrant worker must have a job competency that is squalid, so that an appropriate job training system was needed.

Formal legal-based assistance would be carried out optimally by involving socio-economic potential, community potential through empowering community forums, facilitated by related sectors and synchronized with original regional planning and supported and carried out thoroughly by all relevant community members.

The model of assistance carried out on formal legal-based
- Law No. 24 of 2011 concerning BPJS

migrant workers consists of 4 elements, namely the substance of the legal subject, the substance of legal objects, formal procedures and personal procedures.

Legal personal assistance based on the substance of the related subject matter to migrant workers is carried out in view of cases that occured in the community to migrant workers before leaving to work for recruitment syndicates, and acts of violence when held in the shelter. Of course many parties that could be involved in the process. The companion's job was to provide education through providing knowledge, understanding and self-strengthening to migrant workers to detect and identify those who have predictions of causing loss of property and life safety. Assistance would be carried out easily if there was openness from migrant workers and their families to tell stories openly to all actors from the legal events experienced by migrant workers. Actors could also include related officials or third parties.

Legal personal assistance based on the object of the related problem to migrant workers was carried out considering that the basis of migrant workers was work competency, so that assistants must carry out legal education through the provision of knowledge, understanding and the ability to empower themselves to continue to carry out work activities. Understanding the documents was included in this matter.

Formal procedure-based legal personal assistance for related problems with migrant workers was carried out through the supervision of the implementation of the work placement procedure stage in accordance with existing legal rules.

Personal procedure-based legal personal assistance for related problems with migrant workers carried out through the psychological approach of migrant workers and their families. The four elements of assistance carried out by the companion on the problems experienced by migrant workers before departure are illegal recruitment; document submission; falsifying identities on documents; illegal levies when processing documents in the village; levy imposed by PPPTKIS that are too large; trapped loan sharks before leaving; traded between brokers and PPTKIS; confinement in the shelter because it was made into human stock; extortion by PPTKIS when canceling a work contract; Inadequate shelter conditions while in the shelter are employed at the home of the PPTKIS owner and were not paid on the grounds due to the reason that PKL was difficult to communicate with family; the occurrence of psychological violence and intimidation while being treated; physical violence while in a shelter; sexual harassment while in a shelter; too long waiting for the job order to be held; not given training when in a shelter; training is not done professionally and is merely a formality; uninsured; abuse of work agreement; and neglect of cases when reported to the police

\section{V.CONCLUSION}

Advocacy based on personal legal assistance could be a positive element so that the right to work and a decent living for humanity for Indonesian migrant workers can be fulfilled. 


\section{ACKNOWLEDGEMENTS}

Thank's for Ministry of Research, Technology and Higher Education of the Republic of Indonesia.

\section{REFERENCES}

1. Gui, Y., Berry, J. W., \& Zheng, Y., "Migrant worker acculturation in China," International Journal of Intercultural Relations, 36(4) , p. 598-610, 2012.

2. K. Preibisch, "Pick-your-own labor: Migrant workers and flexibility in Canadian agriculture," International Migration Review, 44(2), p. 404-441, 2010.

3. L. F. Vosko, "Tenuously Unionised: Temporary Migrant Workers and the Limits of Formal Mechanisms Designed to Promote Collective Bargaining in British Columbia," Industrial Law Journal, 43(4), p. 451-484, 2014.

4. H. Yuningrum, "Polemic on Indonesian Workers as a Source of Foreign Exchange (Problematics of Indonesian Workers from the Islamic Aspect)," Economica: Jurnal Ekonomi Islam, 1(2), p. 59, 2017.

5. R. Parwadi, "Policy Dissemination of sending Indonesian Migrant Workers Abroad," Jurnal Kebijakan Publik, 3(1), 2013.

6. E. Baharudin, "Legal Protection of Migrant Workers Abroad Pre-Departure, Placement and Retirement," Lex Jurnalica, 4(3), 2007.

7. A. Hidayah, "Legal Protection of Indonesian Migrant Workers from Time to Time," in National Seminar Paper held by P3HKI- Universitas Flores, Ende, May, 2019.

8. R. Nasution, "The JKPS NGO Advocacy Model Against Migrant Workers from Ponorogo District," Masalah-Masalah Hukum, vol. 46, no. 1, pp. 30-40, 2018.

9. R. Rashid, "Economic Development Strategy, Social Politics In Perspective of Regional Autonomy," in National Seminar Paper held by Faculty of Law Untirta, Banten, June 2000.

10. KBBI, Big Indonesian Dictionary, 2010.

11. R. Parwadi, "Policy Dissemination of sending Indonesian Migrant Workers Abroad," Jurnal Kebijakan Publik, 3(1)., 2013 